\title{
THE LEVELS OF INDIVIDUAL FREE AMINO ACIDS IN THE PLASMA OF NORMAL MAN AT VARIOUS INTERVALS AFTER A HIGH-PROTEIN MEAL ${ }^{1}$
}

\author{
By ELIZABETH G. FRAME \\ (From the Department of Clinical Pathology, Clinical Center, National Institutes of Health, \\ Bethesda, Md.)
}

(Submitted for publication June 19, 1958; accepted July 31, 1958)

The nutritive value of a dietary protein depends on its amino acid content and on the extent of absorption of the amino acids into the blood stream. The criteria which have generally been used for the biological evaluation of ingested proteins are the effect on body weight or nitrogen balance. By the use of such methods it has been demonstrated that utilization does not occur unless the correct assortment of amino acids is presented to the tissues at the same time. The conclusion has followed that the amino acids are not stored as such in the tissues for any length of time. Little is known about the fate in the body of the individual amino acids after protein ingestion, and it was to gain information on this broad subject that the present study was undertaken.

It was shown by Van Slyke and Meyer (1) in 1912 that a high protein meal is followed by an increase in the concentration of total free amino acids in the circulation. They fed beef to fasting dogs, and observed marked increases in the free amino acid nitrogen of the blood five hours later. Similar observations on total free plasma amino acids have been made again in the $\operatorname{dog}(2)$, and in man (3-5).

With the introduction of microbiological and chromatographic methods, it has become feasible to follow the individual amino acids. Dent and Schilling (6) determined the levels of free plasma amino acids in the portal and jugular veins of dogs one, two and one-half and five hours after very large protein meals, using a semi-quantitative paper chromatographic technique. The authors have concluded from their results of feeding casein that the rise in concentration of each of the amino acids in the portal blood, with the exception of glutamic acid, corresponded roughly to the amino

1 Presented before the Tenth Annual Meeting of the American Association of Clinical Chemists, Iowa City, September 4-6, 1958. acid composition of the protein fed. The concentrations in systemic blood were lower than in portal blood. Similarly, Denton and Elvehjem (7), using microbiological assay for 10 amino acids, observed over periods of five or six hours greatly increased levels of amino acids in portal plasma after feeding meals containing casein or beef, while the increases in the radial vein were of smaller magnitude. In almost all cases the peak value was reached earlier in the portal than in the radial vein. The authors commented that the increases in the portal vein appeared to be proportional to the amounts of amino acids supplied by the protein. Wheeler and Morgan (8) followed the effect of feeding meat to rats. The levels of 15 amino acids in portal plasma were determined at intervals up to five hours after the meal, using the method of paper chromatography of the dinitrophenyl derivatives. Marked increases, reaching a peak in 30 or 45 minutes, were observed in all the amino acids; and values at five hours were still well above the fasting levels for at least some of the amino acids. The authors did not relate the increases to the amino acid composition of the ingested protein.

Little information is available on the effect of food intake on the level of the individual plasma free amino acids in man. Wynne and Cott (9), using microbiological assay, studied the levels of six amino acids in nine normal subjects one and three hours after eating a breakfast relatively high in protein; the protein content was not stated. They did not observe a consistent effect on the levels of any of the amino acids measured. Charkey, Kano and Hougham (10) followed the effect of a 48 hour fast on the levels of seven blood amino acids in six normal subjects, using microbiological assay. Their results did not show consistent changes. Six hours after termination of the fast by a meal, the content of which was not 
specified, the changes again were irregular. Using the technique of chromatography on columns of ion exchange resins, Stein, Bearn and Moore (11) measured the free systemic plasma amino acids before and two hours after feeding $50 \mathrm{Gm}$. of casein to a normal subject. They found increases in the levels of most of the amino acids after feeding, and state that "the increase... reflects to some degree, but not in detail, the amino acid composition of the casein fed."

The present work appears to be the first detailed study in any species relating the amino acid composition of the dietary protein to the plasma amino acid levels. In much of the work mentioned above only the essential amino acids have been measured, whereas with the chromatographic technique used here, all of the biologically-important amino acids except glutamine, asparagine and tryptophan are quantitatively determined. In addition, the effects of protein ingestion have not previously been followed for as long a period (eight hours) following the meal as is done in the present study.

\section{METHODS}

Subjects. These were six normal persons between the ages of 24 and 47 years, all from our laboratory staff, Subjects 1, 4 and 6 being females, the others males. After an overnight fast, a sample of blood was drawn from the antecubital vein. The subject then drank the greater part of a mixture of eight raw eggs beaten with one-half pint of milk and a few drops of vanilla. This mixture, whtich will be referred to as "eggnog," amounted to somewhat more than $600 \mathrm{ml}$., and each subject consumed exactly $600 \mathrm{ml}$., usually in two to three minutes. An aliquot of each eggnog was frozen for later total nitrogen and amino acid analyses, so that the exact intake of each amino acid could be determined. No food was eaten during the rest of the experimental period, but water was taken ad lib. Blood samples were drawn from the antecubital vein at various intervals after the meal, and each subject carried on his usual laboratory activities throughout the period. Subject 6, who was followed for eight hours, then ate ad lib. for four hours, again fasted overnight, and a second fasting specimen was drawn.

Preparation of samples. Each blood specimen was drawn into a syringe the dead space of which contained liquid heparin sodium, was centrifuged immediately, and the plasma removed. Ten or $20 \mathrm{ml}$. was promptly deproteinized with picric acid, and an aliquot was frozen for later $\alpha$-amino nitrogen analysis. The protein-free plasma was prepared on the same day for column chromatography as described by Stein and Moore (12).

Column chromatography. The method of Moore and Stein (13) was followed. The same lot of resin (Dowex
$50-X$ 5) was used repeatedly throughout the study. Two $\mathrm{ml}$. effluent fractions were collected and analyzed photometrically by the method of Moore and Stein (14). The amino acids emerged more slowly than described by the original authors, and arginine was not eluted until the effluent volume reached nearly $1,200 \mathrm{ml}$. The sequence of emergence, however, was similar to that of Moore and Stein. Cystine and methionine were identified by running effluent curves of plasma extracts with and without the separate additions of cystine and methionine. With the exception occasionally of methionine and isoleucine, the peaks were well separated. Of the two unidentified peaks in plasma mentioned by Stein and Moore, the one between urea and aspartic acid was seen on all chromatograms and its concentration did not change significantly after the protein meal. The postleucine peak was seen irregularly. A third small unidentified peak was seen in all chromatograms, emerging between cystine and methionine. Its concentration was not changed significantly by the protein ingestion. A tryptophan peak was not seen on any of the plasma effluent curves. In each chromatogram a correction for methionine was made for a 10 per cent loss on the column. Only proline and cystine were corrected for their low color yields with ninhydrin, using the factors of Moore and Stein.

Hydrolysis of deproteinized plasma. In Subjects 1 and $2,20 \mathrm{ml}$. of each plasma sample was deproteinized, and the picric acid removed. Half of the eluate was treated as described above. To the other half was added an equal volume of concentrated $\mathrm{HCl}$ (Analytical Reagent), giving a final concentration of $\mathrm{HCl}$ of $6 \mathrm{~N}$. This was refluxed for 24 hours. The contents of the flask were then reduced in vacuo to about $2 \mathrm{ml}$, water was added several times and removed in vacuo. The residue was brought to $\mathrm{pH} 2$ to 3 and frozen. The chromatograms showed not more than traces of a component in the cysteic acid position. Cystine usually emerged as a double peak, representing the meso- and the $\mathrm{D}$ - or $\mathrm{L}$-forms (15). All effluent curves showed two small peaks or a double peak at the position of the methionine sulfoxides and a peak giving a red color with ninhydrin between taurine and urea, the latter representing carbohydrate decomposition products (16). Of the unidentified peaks, the one between urea and aspartic acid was present in smaller amounts than in the unhydrolyzed specimen; the postleucine peak was not seen; and the one between cystine and methionine was present in about the same amount as before hydrolysis.

Hydrolysis of eggnog. To 1 or $2 \mathrm{ml}$. aliquots of each of the six lots of eggnog, containing about $100 \mathrm{mg}$. of protein per ml., were added 200 volumes of $6 \mathrm{~N} \mathrm{HCl}$, and the mixture was refluxed for 24 hours. The hydrolysate was filtered through sintered glass and the filtrate freed from $\mathrm{HCl}$ as described above. A dark precipitate which formed when the $\mathrm{pH}$ was brought to about 2.5 was removed by centrifugation. The supernate was stored in the frozen state until chromatographed. The effluent curves showed no cysteic acid and only traces of methionine sulfoxides. In common with the protein-free plasma 
TABLE I

A mino acid composition of ingested protein (Gm. per $100 \mathrm{Gm}$. of protein)

\begin{tabular}{lrll}
\hline \hline Alanine & 5.2 & Lysine & 8.1 \\
Arginine & 5.9 & Methionine & 2.9 \\
Aspartic acid & 9.0 & Phenylalanine & 5.0 \\
Cystine & 1.8 & Proline & 4.2 \\
Glutamic acid & 13.8 & Serine & 7.0 \\
Glycine & 3.2 & Threonine & 4.5 \\
Histidine & 2.7 & Tryptophan & $1.5 *$ \\
Isoleucine & 5.3 & Tyrosine & 4.3 \\
Leucine & 8.6 & Valine & 6.8
\end{tabular}

*From Block and Weiss (23).

hydrolysates, they showed a double cystine peak, the red peak with ninhydrin, and the unidentified component between cystine and methionine. A peak between leucine and tyrosine, probably glucosamine, was always seen. The results of the analyses were corrected for a 10 per cent loss of serine and a 5 per cent loss of threonine during hydrolysis. With the single period of hydrolysis used, it was not possible to correct accurately for the destruction or incomplete liberation of some of the amino acids. The results given, therefore, for the content of some of the amino acids in the eggnog may be in error by a few per cent, but not to an extent to interfere with the interpretation of results.

Other analytical techniques. $\alpha$-Amino nitrogen was determined in triplicate on each of the plasma samples by the manometric-carbon dioxide method of Hamilton and Van Slyke (17). The samples had been frozen for varying lengths of time prior to analysis, a procedure which has been found to be without significant effect on the result. Total nitrogen of the eggnog was determined by a macro-Kjeldahl procedure (18). Duplicate $3 \mathrm{ml}$. aliquots of each lot were analyzed. Total nitrogen was multipled by 6.25 to obtain the protein value. Amide nitrogen was determined by the method of Rees (19), with an hydrolysis period of nine days in concentrated $\mathrm{HCl}$ at $37^{\circ} \mathrm{C}$., and urea-nitrogen by Nesslerization of the protein-free filtrate after incubation with urease. Glucose was determined by the method of Somogyi (20), using the color-developing reagent of Nelson (21). A micro hematocrit method was used (22).

Recovery of a-amino nitrogen from column. The $\alpha$-amino nitrogen recovered from each column was calculated and compared with the manometrically-determined $\alpha$-amino nitrogen. Quantitative recovery cannot be expected from the column because glutamine, which makes up about 25 per cent of the total free plasma $\alpha$-amino nitrogen, is destroyed on the column to a variable but large extent; and little, if any, is recovered as glutamic acid. Tryptophan was not found in any of the column eluates. Recovery from the columns varied from 75 to 80 per cent. In Subjects 1 and 2 where aliquots of the deproteinized samples were hydrolyzed, the glutamic acid and aspartic acid levels were used to estimate the glutamine and asparagine of the unhydrolyzed samples. The recovery of $\alpha$-amino nitrogen from the column now rose to 90 to 95 per cent. The calculated recoveries would be further increased if a figure for tryptophan were included and if corrections were made for the color yields of all of the amino acids instead of for only proline and cystine.

\section{RESULTS}

\section{A. Protein intake}

The amounts of protein ingested by Subjects 1 to 6 were $60,55,56,56,51$ and $55 \mathrm{Gm}$., respectively. The percentage amino acid compositions of the six lots of eggnog were in close agreement. Table I illustrates the results; the figures agree reasonably well with those given by Block and Weiss (23) for whole egg. One lot of eggnog was analyzed when fresh for free $\alpha$-amino nitrogen. The result showed that 0.7 per cent of the total nitrogen was present as free $\boldsymbol{\alpha}$-amino nitrogen. In the estimation of protein, the total nitrogen was not corrected for this amount. From the results of the determination of amide nitrogen in one lot of eggnog, 74 per cent of the aspartic acid plus glutamic acid was estimated to be present as amide.

\section{$B$. Total $\alpha$-amino nitrogen in plasma}

The results are shown in Table II. Subjects 1 and 2 were followed for only three hours, at which time the highest observed values were found. Subject 3 was followed for five hours, and showed a peak value at four hours. Subject 4 had a peak level at five hours, although the final value at six hours was still well above the fasting level. Blood samples were drawn from Subjects 5 and 6 at two, four, five, six, seven and eight hours after the meal. Subject 5 had the highest fasting value of any of the subjects and showed the smallest increase after the meal, with a peak at four hours and a return to the fasting level at seven and eight hours. The protein intake of this subject was

TABLE II

Plasma concentrations of $\alpha$-amino nitrogen before and after high-protein meal (mg. per $100 \mathrm{ml}$.)

\begin{tabular}{cccccccccc}
\hline & \multicolumn{10}{c}{ Hours after food } \\
\cline { 2 - 9 } $\begin{array}{c}\text { Subject } \\
\text { no. }\end{array}$ & 0 & 1 & 2 & 3 & 4 & 5 & 6 & 7 & 8 \\
\hline 1 & 3.3 & 4.4 & 4.5 & 4.8 & & & & & \\
2 & 3.8 & 4.9 & 5.4 & 6.1 & & & & & \\
3 & 3.9 & 4.7 & 5.0 & 5.6 & 6.0 & 4.8 & & & \\
4 & 3.8 & & 5.1 & & 5.5 & 5.8 & 4.7 & & \\
5 & 4.6 & & 5.0 & & 5.4 & 5.0 & 4.9 & 4.6 & 4.6 \\
6 & 3.9 & & 4.8 & & 5.1 & 4.8 & 4.8 & 4.8 & 4.3 \\
\hline
\end{tabular}




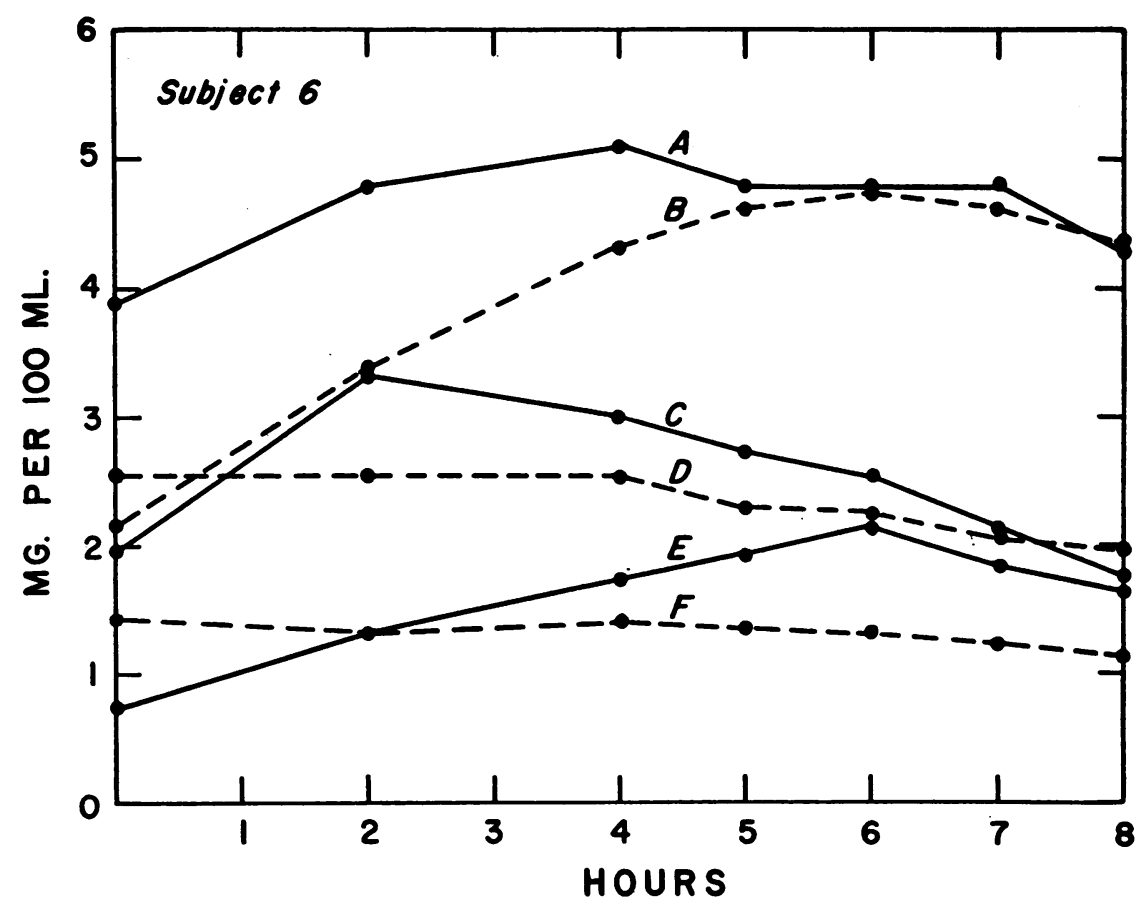

Fig. 1. Plasma Concentrations of Total $\alpha$-Amino Nitrogen (A), Valine (B), Lysine (C), Alanine (D), Isoleucine (E), and Glycine (Not Corrected for Citrulline) (F), Before, and at Various Intervals After, a High-ProTEIN MEal

somewhat less than that of the others. The highest value in Subject 6 was at four hours, but at eight hours the level was still higher than when fasting. In comparing the specimens drawn eight hours after the high-protein meal with the fasting specimens, it should be mentioned that the latter were drawn about 12 hours after meals containing considerably less protein than the experimental meal. The plasma $\alpha$-amino nitrogen of Subject 6 drawn the following morning after a 12 hour fast was $3.6 \mathrm{mg}$. per $100 \mathrm{ml}$., not significantly different from the previous fasting value since the triplicate determinations showed an overlap in results.

\section{Individual free amino acids in plasma}

The data for 20 ninhydrin-positive components are shown in Table III. Those for glutamine plus asparagine are not included because of the low recovery of glutamine from the column. Subjects 1 and 2 were not followed sufficiently long to observe the more interesting results seen in the other subjects. No age or sex differences were noted.
Figure 1 illustrates outstanding results following the high-protein meal.

The patterns of response of the different amino acids after the high-protein meal have been divided into six groups. The distinction between the groups is not always clearcut, and some of the amino acids differ in their pattern from one subject to another ; but for the purpose of summarizing the data the grouping is useful. The characteristics of the group, and their members, are as follows: 1) Marked increase in concentration, with eight hour levels significantly above fasting values. Isoleucine, leucine and valine belong to this group. 2) Moderate increase in concentration, with levels at no time falling below the fasting values. Included here are glutamic acid, methionine, ornithine, phenylalanine, serine, threonine and tyrosine. 3) Moderate or small increase in concentration, but with values at six, seven or eight hours in one or more subjects falling below the fasting values. Cystine, histidine and proline fall into this group. 4) Marked early rise in concentration at two hours, followed by a decrease, 
TABLE III

Plasma concentrations of amino acids before and after high protein meal (mg. per $100 \mathrm{ml}$.)

\begin{tabular}{|c|c|c|c|c|c|c|c|c|c|}
\hline \multirow{2}{*}{$\begin{array}{l}\text { Subject } \\
\text { no. }\end{array}$} & \multicolumn{9}{|c|}{ Hours after food } \\
\hline & 0 & 1 & 2 & 3 & 4 & 5 & 6 & 7 & 8 \\
\hline \multicolumn{10}{|c|}{ Alanine } \\
\hline $\begin{array}{l}1 \\
2 \\
3 \\
4 \\
5 \\
6\end{array}$ & $\begin{array}{l}1.91 \\
2.86 \\
2.54 \\
3.07 \\
3.43 \\
2.57\end{array}$ & $\begin{array}{l}3.30 \\
3.12\end{array}$ & $\begin{array}{l}2.03 \\
3.55 \\
3.11 \\
3.35 \\
3.68 \\
2.57\end{array}$ & $\begin{array}{l}2.01 \\
3.41 \\
3.25\end{array}$ & $\begin{array}{l}3.46 \\
3.18 \\
2.94 \\
2.54\end{array}$ & $\begin{array}{l}2.84 \\
3.11 \\
3.01 \\
2.30\end{array}$ & $\begin{array}{l}2.55 \\
2.27 \\
2.25\end{array}$ & $\begin{array}{l}2.53 \\
2.07\end{array}$ & $\begin{array}{l}2.45 \\
1.99\end{array}$ \\
\hline \multicolumn{10}{|c|}{$\alpha$-Amino- $n$-butyric acid } \\
\hline $\begin{array}{l}1 \\
2 \\
3 \\
4 \\
5 \\
6\end{array}$ & $\begin{array}{l}0.16 \\
0.31 \\
0.13 \\
0.16 \\
0.19 \\
0.08\end{array}$ & $\begin{array}{l}0.25 \\
0.18\end{array}$ & $\begin{array}{l}0.17 \\
0.27 \\
0.14 \\
0.32 \\
0.20 \\
0.16\end{array}$ & $\begin{array}{l}0.38 \\
0.24 \\
0.13\end{array}$ & $\begin{array}{l}0.20 \\
0.21 \\
0.22 \\
0.29\end{array}$ & $\begin{array}{l}0.16 \\
0.27 \\
0.26 \\
0.27\end{array}$ & $\begin{array}{l}0.37 \\
0.32 \\
0.36\end{array}$ & $\begin{array}{l}0.27 \\
0.31\end{array}$ & $\begin{array}{l}0.34 \\
0.35\end{array}$ \\
\hline $\begin{array}{l}1 \\
2 \\
3 \\
4 \\
5 \\
6\end{array}$ & $\begin{array}{l}1.15 \\
1.62 \\
1.45 \\
1.52 \\
1.53 \\
1.58\end{array}$ & $\begin{array}{l}2.22 \\
2.46\end{array}$ & $\begin{array}{l}1.54 \\
2.49 \\
2.38 \\
2.66 \\
1.62 \\
2.14\end{array}$ & $\begin{array}{c}\text { Arg } \\
2.88 \\
2.59\end{array}$ & $\begin{array}{l}2.71 \\
2.41 \\
1.92 \\
2.01\end{array}$ & $\begin{array}{l}2.10 \\
2.69 \\
1.94 \\
1.97\end{array}$ & $\begin{array}{l}1.81 \\
1.39 \\
1.89\end{array}$ & $\begin{array}{l}1.28 \\
1.67\end{array}$ & $\begin{array}{l}1.24 \\
1.45\end{array}$ \\
\hline \multicolumn{10}{|c|}{ Aspartic acid } \\
\hline $\begin{array}{l}1 \\
2 \\
3 \\
4 \\
5 \\
6\end{array}$ & $\begin{array}{l}0.10 \\
0.03 \\
0.04 \\
0.04 \\
0.03 \\
0.01\end{array}$ & $\begin{array}{l}0.08 \\
0.02\end{array}$ & $\begin{array}{l}0.05 \\
0.07 \\
0.04 \\
0.04 \\
0.01 \\
0.05\end{array}$ & $\begin{array}{l}0.08 \\
0.09 \\
0.07\end{array}$ & $\begin{array}{l}0.06 \\
0.07 \\
0.08 \\
0.05\end{array}$ & $\begin{array}{l}0.03 \\
0.07 \\
0.43 \\
0.04\end{array}$ & $\begin{array}{l}0.04 \\
0.05 \\
0.04\end{array}$ & $\begin{array}{l}0.04 \\
0.03\end{array}$ & $\begin{array}{l}0.06 \\
0\end{array}$ \\
\hline \multicolumn{10}{|c|}{ Cystine } \\
\hline $\begin{array}{l}1 \\
2 \\
3 \\
4 \\
5 \\
6\end{array}$ & $\begin{array}{l}1.05 \\
0.75 \\
1.03 \\
1.11 \\
1.23 \\
1.42\end{array}$ & $\begin{array}{l}0.89 \\
1.27\end{array}$ & $\begin{array}{l}1.10 \\
1.34 \\
1.35 \\
1.27 \\
1.42 \\
1.49\end{array}$ & $\begin{array}{l}1.36 \\
1.29 \\
1.35\end{array}$ & $\begin{array}{l}1.52 \\
1.23 \\
1.45 \\
1.49\end{array}$ & $\begin{array}{l}1.24 \\
1.19 \\
1.37 \\
1.51\end{array}$ & $\begin{array}{l}0.96 \\
1.25 \\
1.53\end{array}$ & $\begin{array}{l}1.22 \\
1.36\end{array}$ & $\begin{array}{l}1.13 \\
1.28\end{array}$ \\
\hline \multicolumn{10}{|c|}{ Glutamic acid } \\
\hline $\begin{array}{l}1 \\
2 \\
3 \\
4 \\
5 \\
6\end{array}$ & $\begin{array}{l}0.45 \\
0.51 \\
0.27 \\
0.62 \\
0.49 \\
0.31\end{array}$ & $\begin{array}{l}0.88 \\
0.55\end{array}$ & $\begin{array}{l}0.65 \\
0.95 \\
0.43 \\
0.82 \\
0.69 \\
0.58\end{array}$ & 0.53 & $\begin{array}{l}1.06 \\
1.13 \\
0.62 \\
0.65 \\
0.68 \\
0.60\end{array}$ & $\begin{array}{l}0.33 \\
0.87 \\
1.30 \\
0.73\end{array}$ & $\begin{array}{l}0.66 \\
0.69 \\
0.62\end{array}$ & $\begin{array}{l}0.78 \\
0.48\end{array}$ & $\begin{array}{l}0.80 \\
0.38\end{array}$ \\
\hline \multicolumn{10}{|c|}{ Glycine* } \\
\hline $\begin{array}{l}1 \\
2 \\
3 \\
4 \\
5 \\
6\end{array}$ & $\begin{array}{l}2.40 \\
1.77 \\
1.89 \\
1.48 \\
2.09 \\
1.48\end{array}$ & $\begin{array}{l}1.85 \\
2.00\end{array}$ & $\begin{array}{l}2.53 \\
1.92 \\
2.07 \\
1.43 \\
1.96 \\
1.34\end{array}$ & $\begin{array}{l}2.53 \\
1.96 \\
1.99\end{array}$ & $\begin{array}{l}2.01 \\
1.32 \\
1.94 \\
1.42\end{array}$ & $\begin{array}{l}1.66 \\
1.32 \\
1.91 \\
1.37\end{array}$ & $\begin{array}{l}1.11 \\
1.74 \\
1.32\end{array}$ & $\begin{array}{l}1.73 \\
1.26\end{array}$ & $\begin{array}{l}1.69 \\
1.15\end{array}$ \\
\hline \multicolumn{10}{|c|}{ Histidine } \\
\hline $\begin{array}{l}1 \\
2 \\
3 \\
4 \\
5 \\
6\end{array}$ & $\begin{array}{l}0.97 \\
1.42 \\
1.11 \\
1.09 \\
1.18 \\
1.33\end{array}$ & $\begin{array}{l}1.65 \\
1.27\end{array}$ & $\begin{array}{l}1.08 \\
1.88 \\
1.31 \\
1.16 \\
1.31 \\
1.56\end{array}$ & $\begin{array}{l}1.28 \\
1.97 \\
1.18\end{array}$ & $\begin{array}{l}1.30 \\
1.28 \\
1.32 \\
1.40\end{array}$ & $\begin{array}{l}1.16 \\
1.18 \\
1.33 \\
1.31\end{array}$ & $\begin{array}{l}1.00 \\
1.27 \\
1.22\end{array}$ & $\begin{array}{l}1.41 \\
1.32\end{array}$ & $\begin{array}{l}1.11 \\
1.17\end{array}$ \\
\hline
\end{tabular}

* Not corrected for citrulline. 
PLASMA FREE AMINO ACIDS AFTER PROTEIN MEAL

TABLE III-Continued

\begin{tabular}{|c|c|c|c|c|c|c|c|c|c|}
\hline \multirow{2}{*}{$\begin{array}{c}\text { Subject } \\
\text { no. }\end{array}$} & \multicolumn{9}{|c|}{ Hours after food } \\
\hline & 0 & 1 & 2 & 3 & 4 & 5 & 6 & 7 & 8 \\
\hline \multicolumn{10}{|c|}{ Isoleucine } \\
\hline $\begin{array}{l}1 \\
2 \\
3 \\
4 \\
5 \\
6\end{array}$ & $\begin{array}{l}0.73 \\
0.79 \\
0.60 \\
0.76 \\
0.68 \\
0.76 \dagger\end{array}$ & $\begin{array}{l}1.46 \\
1.07\end{array}$ & $\begin{array}{l}1.24 \\
1.71 \\
1.12 \\
1.55 \\
1.54 \dagger \\
1.32 \dagger\end{array}$ & $\begin{array}{l}2.21 \\
2.39 \\
1.55\end{array}$ & $\begin{array}{l}2.18 \\
2.30 \\
1.49 \dagger \\
1.71\end{array}$ & $\begin{array}{l}1.53 \\
2.28 \\
1.67 \\
1.93\end{array}$ & $\begin{array}{l}1.50 \\
1.34 \\
2.17\end{array}$ & $\begin{array}{l}1.29 \\
1.86\end{array}$ & $\begin{array}{l}1.23 \\
1.66\end{array}$ \\
\hline \multicolumn{10}{|c|}{ Leucine } \\
\hline $\begin{array}{l}1 \\
2 \\
3 \\
4 \\
5 \\
6\end{array}$ & $\begin{array}{l}1.31 \\
1.63 \\
1.15 \\
1.36 \\
1.36 \\
1.12\end{array}$ & $\begin{array}{l}2.49 \\
1.87\end{array}$ & $\begin{array}{l}2.34 \\
3.14 \\
2.12 \\
2.60 \\
2.24 \\
2.25\end{array}$ & $\begin{array}{l}3.04 \\
3.94 \\
2.72\end{array}$ & $\begin{array}{l}3.15 \\
3.29 \\
2.55 \\
2.77\end{array}$ & $\begin{array}{l}2.50 \\
3.48 \\
2.77 \\
2.94\end{array}$ & $\begin{array}{l}2.48 \\
2.19 \\
3.11\end{array}$ & $\begin{array}{l}2.08 \\
2.84\end{array}$ & $\begin{array}{l}1.99 \\
2.28\end{array}$ \\
\hline \multicolumn{10}{|c|}{ Lysine } \\
\hline $\begin{array}{l}1 \\
2 \\
3 \\
4 \\
5 \\
6\end{array}$ & $\begin{array}{l}1.87 \\
2.96 \\
2.08 \\
2.94 \\
2.15 \\
1.93\end{array}$ & $\begin{array}{l}4.90 \\
3.43\end{array}$ & $\begin{array}{l}2.78 \\
5.50 \\
3.63 \\
4.75 \\
3.30 \\
3.32\end{array}$ & $\begin{array}{l}2.77 \\
5.75 \\
3.76\end{array}$ & $\begin{array}{l}3.72 \\
4.18 \\
2.99 \\
3.00\end{array}$ & $\begin{array}{l}2.74 \\
4.31 \\
2.63 \\
2.74\end{array}$ & $\begin{array}{l}3.11 \\
2.06 \\
2.56\end{array}$ & $\begin{array}{l}2.05 \\
2.12\end{array}$ & $\begin{array}{l}1.81 \\
1.78\end{array}$ \\
\hline \multicolumn{10}{|c|}{ Methionine } \\
\hline $\begin{array}{l}1 \\
2 \\
3 \\
4 \\
5 \\
6\end{array}$ & $\begin{array}{l}0.27 \\
0.44 \\
0.33 \\
0.21 \\
0.44 \\
0.20 \dagger\end{array}$ & $\begin{array}{l}0.53 \\
0.57\end{array}$ & $\begin{array}{l}0.41 \\
0.82 \\
0.76 \\
0.57 \\
0.42 \dagger \\
0.56 \dagger\end{array}$ & $\begin{array}{l}0.23 \\
1.00 \\
0.83\end{array}$ & $\begin{array}{l}0.89 \\
0.63 \\
0.72 \dagger \\
0.54\end{array}$ & $\begin{array}{l}0.84 \\
0.94 \\
0.67 \\
0.52\end{array}$ & $\begin{array}{l}0.77 \\
0.59 \\
0.53\end{array}$ & $\begin{array}{l}0.56 \\
0.48\end{array}$ & $\begin{array}{l}0.44 \\
0.39\end{array}$ \\
\hline \multicolumn{10}{|c|}{ Ornithine } \\
\hline $\begin{array}{l}1 \\
2 \\
3 \\
4 \\
5 \\
6\end{array}$ & $\begin{array}{l}0.62 \\
0.60 \\
0.63 \\
0.77 \\
0.68 \\
0.63\end{array}$ & $\begin{array}{l}1.10 \\
0.93\end{array}$ & $\begin{array}{l}1.09 \\
1.29 \\
0.94 \\
1.34 \\
1.00 \\
1.12\end{array}$ & $\begin{array}{l}1.42 \\
1.36 \\
1.08\end{array}$ & $\begin{array}{l}1.00 \\
1.37 \\
0.99 \\
1.15\end{array}$ & $\begin{array}{l}0.94 \\
1.55 \\
0.93 \\
1.12\end{array}$ & $\begin{array}{l}1.35 \\
0.86 \\
1.15\end{array}$ & $\begin{array}{l}0.74 \\
1.12\end{array}$ & $\begin{array}{l}0.65 \\
0.96\end{array}$ \\
\hline \multicolumn{10}{|c|}{ Phenylalanine } \\
\hline $\begin{array}{l}1 \\
2 \\
3 \\
4 \\
5 \\
6\end{array}$ & $\begin{array}{l}0.70 \\
0.83 \\
0.81 \\
1.20 \\
0.97 \\
1.00\end{array}$ & $\begin{array}{l}0.88 \\
0.98\end{array}$ & $\begin{array}{l}0.94 \\
1.08 \\
1.04 \\
1.47 \\
0.99 \\
1.08\end{array}$ & $\begin{array}{l}1.29 \\
1.20\end{array}$ & $\begin{array}{l}1.58 \\
1.14 \\
1.13 \\
1.23\end{array}$ & $\begin{array}{l}1.19 \\
1.75 \\
1.31 \\
1.31\end{array}$ & $\begin{array}{l}1.37 \\
1.09 \\
1.35\end{array}$ & $\begin{array}{l}1.02 \\
1.49\end{array}$ & $\begin{array}{l}0.98 \\
1.60\end{array}$ \\
\hline \multicolumn{10}{|c|}{ Proline } \\
\hline $\begin{array}{l}1 \\
2 \\
3 \\
4 \\
5 \\
6\end{array}$ & $\begin{array}{l}1.37 \\
2.64 \\
1.63 \\
1.42 \\
2.30 \\
1.43\end{array}$ & $\begin{array}{l}2.91 \\
1.53\end{array}$ & $\begin{array}{l}1.73 \\
2.92 \\
1.25 \\
0.80 \\
2.50 \\
1.56\end{array}$ & $\begin{array}{l}2.19 \\
3.05 \\
1.66\end{array}$ & $\begin{array}{l}2.40 \\
1.78 \\
2.75 \\
2.02\end{array}$ & $\begin{array}{l}2.00 \\
2.01 \\
2.46 \\
1.91\end{array}$ & $\begin{array}{l}1.61 \\
2.11 \\
1.68\end{array}$ & $\begin{array}{l}2.11 \\
1.64\end{array}$ & $\begin{array}{l}1.93 \\
1.47\end{array}$ \\
\hline \multicolumn{10}{|c|}{ Serine } \\
\hline $\begin{array}{l}1 \\
2 \\
3 \\
4 \\
5 \\
6\end{array}$ & $\begin{array}{l}0.83 \\
0.97 \\
0.93 \\
1.01 \\
1.27 \\
0.82\end{array}$ & $\begin{array}{l}1.29 \\
1.22\end{array}$ & $\begin{array}{l}1.08 \\
1.48 \\
1.35 \\
1.22 \\
1.54 \\
1.04\end{array}$ & $\begin{array}{l}1.42 \\
1.69 \\
1.54\end{array}$ & $\begin{array}{l}1.72 \\
1.32 \\
1.69 \\
1.26\end{array}$ & $\begin{array}{l}1.44 \\
1.50 \\
1.86 \\
1.24\end{array}$ & $\begin{array}{l}1.16 \\
1.54 \\
1.34\end{array}$ & $\begin{array}{l}1.52 \\
1.14\end{array}$ & $\begin{array}{l}1.42 \\
1.03\end{array}$ \\
\hline
\end{tabular}

$\dagger$ Values inaccurate because of incomplete separation of isoleucine and methionine. 
TABLE III-Continued

\begin{tabular}{|c|c|c|c|c|c|c|c|c|c|}
\hline \multirow{2}{*}{$\begin{array}{l}\text { Subject } \\
\text { no. }\end{array}$} & \multicolumn{9}{|c|}{ Hours after food } \\
\hline & $\mathbf{0}$ & 1 & 2 & 3 & 4 & 5 & 6 & 7 & 8 \\
\hline \multicolumn{10}{|c|}{ Taurine } \\
\hline 1 & $\begin{array}{l}2.10 \\
0.47\end{array}$ & & 1.33 & $\begin{array}{l}1.78 \\
1.08\end{array}$ & & & & & \\
\hline $\begin{array}{l}2 \\
3\end{array}$ & $\begin{array}{l}0.47 \\
0.80\end{array}$ & $\begin{array}{l}1.11 \\
0.63\end{array}$ & $\begin{array}{l}0.91 \\
0.55\end{array}$ & $\begin{array}{l}1.08 \\
0.95\end{array}$ & 0.95 & 0.66 & & & \\
\hline 4 & 1.25 & & 0.94 & & & 0.81 & 0.79 & & \\
\hline 5 & 0.60 & & 0.77 & & 0.72 & 0.63 & 0.76 & 0.64 & 0.75 \\
\hline 6 & 0.40 & & 0.46 & & 0.39 & 0.50 & 0.42 & 0.42 & 0.56 \\
\hline \multicolumn{10}{|c|}{ Threonine } \\
\hline 1 & 0.94 & & 1.33 & 1.70 & & & & & \\
\hline 2 & $\begin{array}{l}1.47 \\
1.52\end{array}$ & $\begin{array}{l}1.96 \\
1.84\end{array}$ & $\begin{array}{l}2.18 \\
2.18\end{array}$ & $\begin{array}{r}2.43 \\
2.19\end{array}$ & & & & & \\
\hline 4 & 1.05 & & 1.70 & & 1.75 & 1.89 & 1.54 & & \\
\hline 5 & 1.75 & & 2.17 & & 2.31 & 2.28 & 2.00 & 1.91 & 1.78 \\
\hline 6 & 1.45 & & 1.80 & & 2.06 & 2.06 & 2.08 & 1.87 & 1.69 \\
\hline \multicolumn{10}{|c|}{ Tyrosine } \\
\hline 1 & 0.57 & & 0.91 & & & & & & \\
\hline 2 & 1.00 & 1.21 & 1.56 & 1.74 & & & & & \\
\hline $\begin{array}{r}3 \\
4\end{array}$ & $\begin{array}{l}0.79 \\
121\end{array}$ & 1.21 & $\begin{array}{l}1.38 \\
2.18\end{array}$ & 1.60 & $\begin{array}{l}1.91 \\
2.38\end{array}$ & $\begin{array}{l}1.59 \\
2.52\end{array}$ & & & \\
\hline 5 & 1.22 & & 1.62 & & 1.79 & 1.76 & 1.36 & 1.28 & 1.18 \\
\hline 6 & 0.68 & & 1.36 & & 1.53 & 1.56 & 1.59 & 1.55 & 1.10 \\
\hline \multicolumn{10}{|c|}{ Valine } \\
\hline 1 & 2.32 & & 3.07 & 4.46 & & & & & \\
\hline 2 & 2.78 & 3.46 & 4.24 & 5.50 & & & & & \\
\hline 3 & 1.95 & 2.64 & 3.06 & 3.78 & 4.68 & 4.20 & & & \\
\hline 4 & 2.20 & & 3.89 & & 5.44 & 5.87 & 5.17 & & \\
\hline 5 & 2.41 & & 3.18 & & 4.00 & 4.16 & 3.80 & 3.52 & 3.43 \\
\hline 6 & 2.15 & & 3.39 & & 4.32 & 4.63 & 4.78 & 4.66 & 4.39 \\
\hline
\end{tabular}

with values at six, seven or eight hours below the fasting levels. Lysine, particularly, and also arginine, follow this pattern. 5) No early change or a slight early increase in concentration, followed by a progressive decrease to values significantly below the fasting levels. Alanine and glycine (not corrected for citrulline) belong to this group. 6) No significant change. Aspartic acid and aminobutyric acid are in this group, and also taurine, with its irregular changes. It may be that the variable results for taurine are due to lysis of leucocytes and platelets, as suggested by the work of McMenamy, Lund and Oncley (24).

Since glutamine is partially destroyed on the column, the chromatographic results for the glutamine plus asparagine peak are of limited value. If one can assume that a constant proportion is destroyed when all samples are treated alike, as was the case in the present study, tentative conclusions may be drawn. Increases in concentration of 11 to 55 per cent were seen in five of the subjects in two to four hours. Three out of four subjects showed values below the fasting levels at five to eight hours. In Subjects 1 and 2 where the protein-free filtrates were hydrolyzed and chromatographed, the glutamine and asparagine were estimated, assuming that the additional glutamic and aspartic acids in the hydrolysate were derived only from their amides. In Subject 1 the estimated glutamine levels at fasting, two and three hours were $7.3,8.7$ and $8.0 \mathrm{mg}$. per $100 \mathrm{ml}$; and asparagine, $0.8,1.2$ and $1.2 \mathrm{mg}$. per $100 \mathrm{ml}$. In Subject 2, glutamine concentrations at fasting, one, two and three hours were 10.2, 10.1, 9.8 and 10.6 mg. per $100 \mathrm{ml}$., and the corresponding values for asparagine were $1.6,1.3,1.4$ and $1.5 \mathrm{mg}$. per $100 \mathrm{ml}$. Although direct evidence is not available, the indications are that the plasma levels of glutamine and asparagine increased only slightly after protein ingestion, and may have decreased below the fasting values at the later time intervals.

The failure of total $\alpha$-amino nitrogen to give an adequate picture of the effect of protein feeding on plasma amino acid concentration is illustrated in 


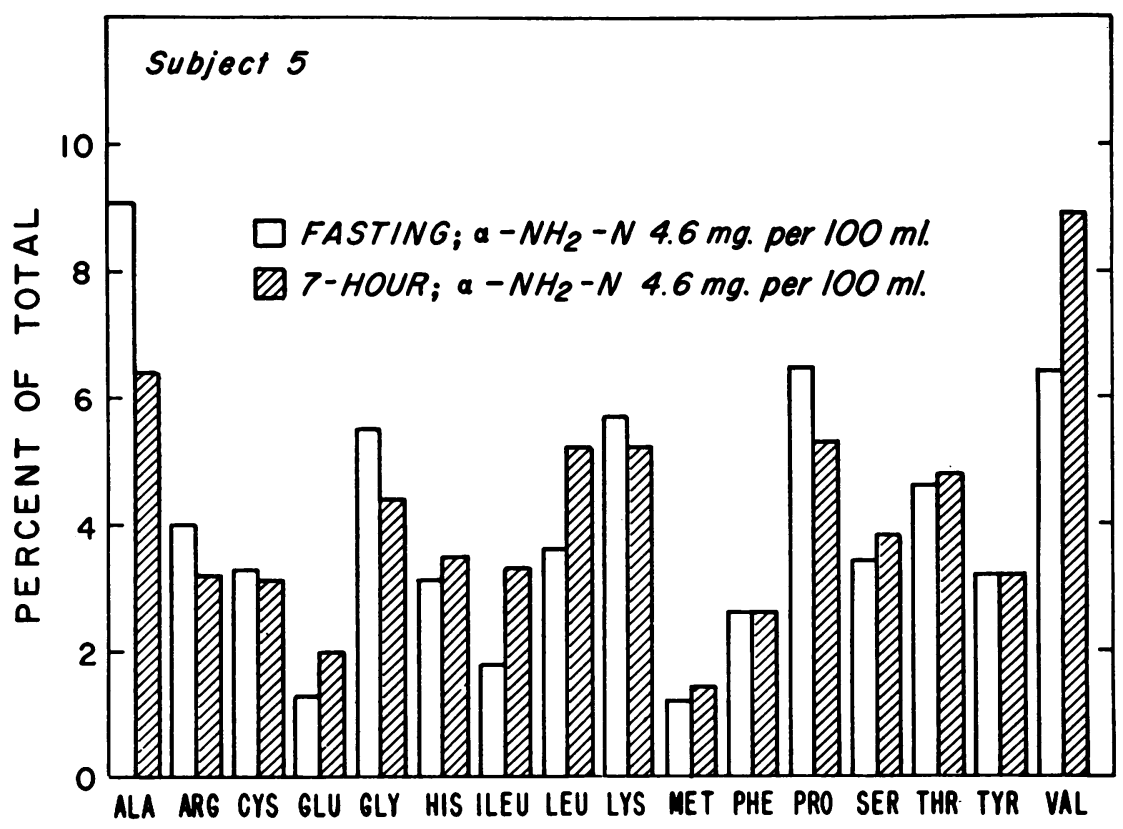

Fig. 2. Relative Concentrations of the Individual Free Plasma Amino Acids in the Fasting State and Seven Hours After a High-Protein Meal

The abbreviations represent the first three letters of the amino acids listed in Table I.

Figure 2. Here, the individual amino acids in the fasting and seven hour specimens of Subject 5, both of which had $4.6 \mathrm{mg}$. per $100 \mathrm{ml}$. of $\alpha$-amino nitrogen, are expressed as per cent of the total amino acids. The numerical values are not accurate because only approximate data for glutamine and asparagine were available, and tryptophan was not included. It is clear, however, that the relative distribution of the different amino acids is quite dissimilar in the two samples in spite of identical total $\alpha$-amino nitrogen concentrations.

TABLE IV

Average index* of four subjects four hours after meal

\begin{tabular}{lllc}
\hline \hline Valine & 66 & Arginine & 22 \\
Isoleucine & 45 & Cystine & 20 \\
Tyrosine & 39 & Phenylalanine & 15 \\
Leucine & 36 & Serine & 13 \\
Threonine & 29 & Histidine & 12 \\
Lysine & 28 & Glycine $\dagger$ & neg. \\
Methionine & 26 & Alanine & neg. \\
Proline & 24 & &
\end{tabular}

${ }^{*}$ Index $=\frac{\mathrm{mg} \text {. per } 100 \mathrm{ml} \text {. increase over fasting level } \times 100}{\mathrm{Gm}}$ t Not corrected for citrulline.

\$ Negative in three of four subjects.

$\$$ Negative in two of four subjects.

\section{Food-plasma index}

A number of physiological mechanisms are involved in determining the effect of the ingestion of a protein on the concentration of the different amino acids in the systemic circulation. These are discussed below. Although the details of the dynamic processes are not known, it seems worthwhile to estimate the overall effect of protein intake on plasma amino acid levels. The following index is proposed as a means of relating numerically, for each amino acid, the change in concentration in the plasma which follows the meal to its content in the ingested protein:

$\frac{\mathrm{Mg} \text {. per } 100 \mathrm{ml} \text {. increase over fasting level } \times 100}{\mathrm{Gm} . \text { in ingested protein }}$.

Illustrative values of such an index are shown in Table IV which gives for 15 amino acids the average index of the four subjects four hours after the meal, a time at which most of the amino acids are at, or close to, their highest concentrations. The differences in index values among the subjects at any one time interval are not great. It is evident from the variability of the indices that the extent of the increase in concentration of an amino 
acid does not parallel the amount in the ingested protein. The average index varies from 66 for valine to 12 for histidine. At four hours two of the four subjects show a negative value for alanine, with the other two subjects having index values of 4 and 13. At four hours three of four subjects have a negative index for glycine (uncorrected for citrulline), while the fourth subject has an index of 3. The negative values are shared at later time intervals in one or more subjects by arginine, cystine, histidine, lysine and proline.

If the index is expressed as per cent, rather than absolute, increase over the fasting levels, the order of indices becomes quite different, with methionine assuming the highest index, and the others in the following order of decreasing value: isoleucine, tyrosine, valine, leucine, threonine, cystine, arginine, proline, serine, lysine, phenylalanine and histidine.

\section{E. Other analytical data}

Glucose. Blood glucose levels were determined only in Subject 3. The fasting value was $92 \mathrm{mg}$. per $100 \mathrm{ml}$., and at succeeding hourly intervals the values were $72,82,90,74$ and $80 \mathrm{mg}$. per $100 \mathrm{ml}$.

Urea-nitrogen. Blood urea-nitrogen was determined on each sample from Subjects 4 and 6. The levels rose progressively throughout the experimental period, from fasting values of 9 and $11 \mathrm{mg}$. per $100 \mathrm{ml}$. to 16 and $19 \mathrm{mg}$. per $100 \mathrm{ml}$.

Hematocrit. A 35 to $40 \mathrm{ml}$. sample of blood was drawn from each subject at each time interval. Since this meant a total removal of about $280 \mathrm{ml}$. of blood from Subjects 5 and 6, with less from the other subjects, it seemed possible that the decrease in concentration of some of the amino acids with time might be due to blood removal with a consequent dilution of the plasma. The hematocrit values were determined on Subject 6 . With a value of 42 in the fasting sample, the level decreased progressively to 39 at seven hours, and rose to 40 at eight hours. A drop in hematocrit from 42 to 39 represents an increase of 5 per cent in plasma volume. Even if this dilution of plasma were brought about by amino acid-free fluid, it could not account for the much greater per cent decreases in concentration seen for a number of the amino acids.
Nonprotein combined amino acids. These were determined only in Subjects 1 and 2. Except for aspartic and glutamic acids, which increased greatly, the changes in concentration of the different amino acids after hydrolysis were small and irregular, and a consistent effect of the protein meal was not found.

Fasting specimen 2, Subject 6. Compared with the fasting specimen of the preceding day, the second one showed slightly lower concentrations of alanine, cystine and arginine, and a higher valine level. The blood urea-nitrogen was $5 \mathrm{mg}$. per $100 \mathrm{ml}$. higher than on the preceding day.

\section{DISCUSSION}

The data show that the ingestion of a meal high in protein is followed by changes in the concentration of each of the free circulating amino acids, and that these changes do not parallel the relative amino acid composition of the protein ingested; nor do the relative concentrations of the different amino acids in the plasma remain constant. There are several factors which may contribute to the observed results :

1. The amino acids may be released from the dietary protein in the gastrointestinal tract at different rates and to different extents. Several in vitro studies (25-27), where protein was incubated with one or more proteolytic enzymes, indicate that under the conditions used, amino acids are liberated at different rates. It is difficult to apply these observations to in vivo conditions, especially as the in vitro incubation periods extended for 72 hours or longer. However, it is possible that digestion may be a factor in determining the variable changes in plasma levels of the different amino acids.

2. The amino acids may be absorbed from the intestine at different rates and to different extents. A number of in vitro studies (28-32), using mostly the isolated loop of the rat intestine, demonstrate that different amino acids are absorbed at different rates, and that the presence of one amino acid may affect the absorption of another. It may be that in vivo, also, the rate and extent of absorption are not governed entirely by the concentration in the intestine.

3. Dietary ingredients other than protein may influence the plasma amino acid levels. Munro 
and Thomson (33) found that the oral ingestion of $50 \mathrm{Gm}$. of glucose by normal adults was followed two hours later by a decrease in the concentration of the seven plasma amino acids measured. Fridhandler and Quastel (31) observed that a high concentration of glucose inhibited the absorption of alanine in the perfused guinea pig intestine. In the present study, the total carbohydrate of the ingested meal was only about $12 \mathrm{Gm}$., and in the one subject where blood sugar concentrations were measured the changes were minimal. Munro and Thomson (33) did not observe a significant effect on the plasma amino acids after the ingestion of $30 \mathrm{Gm}$. of butter. It seems unlikely that either the fat (approximately $50 \mathrm{Gm}$.) or carbohydrate ingredients of the meal in the present study influenced the effects of the protein component.

Information on points 1,2 and 3 should be gained by observing the effect on the plasma amino acid levels of the ingestion of purified amino acids, one at a time or together, in amounts equal to those present in the protein. Such studies have already been done by Steele and Le Bovit (34) on humans for two amino acids, using microbiological asay. After the ingestion of $5 \mathrm{Gm}$. of leucine or $1.5 \mathrm{Gm}$. of histidine (amounts comparable to those in the ingested protein of the present study), the plasma concentrations of the administered amino acid reached much higher levels than those seen in the present work, with peaks at 30 minutes, which is considerably earlier than seen in our study. The results suggest that the effect on the plasma level of the ingestion of an amino acid may be quite different depending on whether the amino acid is given alone in the free form or fed as part of a protein molecule. On the other hand, Gupta, Dakroury and Harper (35) found that total nitrogen disappeared from the gastrointestinal tract of rats at nearly the same rate whether the diet contained casein, beef or a mixture of amino acids.

4. Some of the amino acids may be excreted into the urine. Urinary amino acids were not studied in the present work, but the investigations of others indicate that although small amounts of the ingested amino acids are excreted, the loss by this route is not large on a percentage basis. By continuous intravenous infusion into humans of a mixture of 18 amino acids, Doolan, Harper,
Hutchin and Shreeve (36) raised the plasma levels to values at least equal to, and in many instances far exceeding, those reached in the present study and found very slight increases in urinary amino acid excretion. The overall loss was less than 4 per cent of the administered amino acids.

5. The amino acids may be removed by the tissues at different rates and to different extents. That intravenously administered amino acids are rapidly removed by the tissues from the blood stream of the dog was shown many years ago by Van Slyke and Meyer $(1,37)$. In man, also, intravenously administered glycine, methionine and lysine have been found to disappear rapidly (3840). When the diet is the source of the additional amino acids, the liver assumes particular importance in their disposal. Several investigators (2, $6,7)$ whose work was discussed above found higher levels of amino acids in the plasma of the portal vein than in the systemic circulation of dogs after a protein meal. The differences between portal and systemic blood found by Denton and Elvehjem (7) after casein feeding are much greater than those seen by Dent and Schilling (6) and Christensen (2), although the latter gave larger amounts of casein. Differences in methodology may account for the discrepancy. The results of Onen, Wade and Blainey (41) indicate that free amino acids are removed from the plasma by the liver of humans even in the fasting state. Using a semi-quantitative paper chromatographic technique in fasting subjects undergoing heart catheterization, these workers found that the plasma concentrations of the leucines, valine, alanine, cysteic acid, methionine, glycine and glutamine were lower in the hepatic vein than in the radial artery. Glutamic acid, the only other amino acid measured, varied from one subject to another in its relative concentrations in hepatic vein and radial artery. Since the concentration of free plasma amino acids is maintained at a fairly constant level except after a high-protein meal, there must be a net contribution of amino acids to the plasma from tissues other than the liver. A discussion of the mechanisms which may control the levels of the free circulating plasma amino acids during fasting or after feeding is beyond the scope of this paper. In the present study, the influx of amino acids from the intestine had passed through the liver 
and into the systemic circulation before analysis; and the observed levels represent the pattern of plasma amino acids presented to tissues other than the liver.

Nasset, Schwartz and Weiss (42) have concluded from their studies on dogs that considerable amounts of endogenous protein are returned to the lumen of the digestive tract during digestion as enzyme protein and mucosal cells. It is not possible to estimate the extent to which this occurs in the present study. It is likely, however, that the intestinal mucosa is one of the tissues removing amino acids from the systemic circulation. The studies of Borsook and his collaborators (43), showing the very rapid disappearance of $\mathrm{C}^{14}$ labeled glycine, histidine, leucine and lysine from the blood of mice and their prompt appearance in the tissue proteins, cannot be correlated with the present type of study where only net changes in concentration are measured with no information on exchange.

Of the total amino acids contained in the ingested protein, only a small proportion appears as increases in the plasma and extracellular fluid. The observation that the blood urea-nitrogen concentrations increased significantly and continued to increase after the amino acid level had reached a peak is evidence that the amino acids are continuing to be deaminated. It is of interest that, although ornithine was not found in the acid hydrolysates of the ingested protein, the plasma ornithine concentrations rose after a protein meal up to twice the fasting levels, an observation made previously by Stein, Bearn and Moore (11). The effect of a protein meal on plasma citrulline levels was not measured in the present work since glycine and citrulline were not separated from each other; nor has the literature been found to contain information on this point.

The observation that the concentrations of some amino acids decrease below the fasting levels at a time when others are increasing or are still well above the fasting values is of considerable interest. The most striking example is alanine which in one subject fell to 66 per cent of the fasting concentration. The results with glycine are less clearcut because of its failure to be separated from citrulline. The two together fell to as low as 75 per cent of the fasting value. It seems unlikely that the plasma citrulline concentration has decreased, especially in the presence of a rising ornithine level; and the drop in glycine plus citrulline probably represents a decreased glycine concentration. Glycine and alanine are known to be among the most metabolically active of the amino acids and to have functions other than as protein components. One can speculate that in the handling by the tissues of the influx of amino acids after a protein meal these two amino acids are rapidly utilized. A practical inference from the present study is that glycine and alanine may be less sensitive than other amino acids as test substances in the study of intestinal absorption in man. Glycine has frequently been used for this purpose, most recently by Butterworth, Santini and PerezSantiago (44).

The nutritional implications of the results presented in this paper are of interest. It is frequently quoted in the literature that all the essential amino acids must be presented to the tissues almost simultaneously for their utilization to occur. The specific data on which such a general statement is based are as follows: Cannon and co-workers (45) fed to protein-depleted rats alternately, at hourly intervals, with a one hour fasting period between, two groups of amino acids, one containing arginine, histidine, leucine, lysine and threonine, the other isoleucine, methionine, phenylalanine, tryptophan and valine. The rats failed to grow, indicating that all five amino acids of either group are not available for tissue protein synthesis one to two hours after ingestion. Working also with rats, Geiger (46) found that if diets deficient in tryptophan, methionine or lysine were supplemented with the missing amino acid 12 hours later effective growth did not occur. Geiger (47) observed also that when two kinds of protein, each of low biological value, were fed together to rats, growth occured; but if the two proteins were offered alternately, each for 10 hours, with a twohour fasting period between, growth did not take place. Henderson and Harris (48) observed that a delay of three hours in the feeding of lysine as a supplement to a lysine-low diet interfered with nitrogen retention and gain of body weight in rats. In dogs, Elman (49) found that when the intravenous injection of an amino acid solution deficient in tryptophan was followed after six hours 
by the intravenous injection of tryptophan, positive nitrogen balance was not achieved. The only comparable study in humans appears to be that of Leverton and Gram (50) who showed that a positive nitrogen balance was increased if the dietary animal protein was distributed among the three meals a day rather than being consumed only at lunch and dinner. In none of the species studied has there been a clear definition of the maximum time interval at which a missing amino acid may still be effectively supplied. In the two subjects in the present study who were followed for as long as eight hours after the protein meal, the plasma levels of all the essential amino acids except lysine (tryptophan was not measured) were at that time at least equal to, and for several amino acids markedly above, the fasting values. If prolonged plasma elevation means intracellular saturation, one might anticipate that leucine, isoleucine and valine, particularly, would be available for utilization by the human several hours after their ingestion.

In the nutritive evaluation of proteins, emphasis has been focussed largely on their essential amino acid content. However, Geiger (51) and Leverton (52), among others, have raised the question whether the dispensable amino acids may not at times become limiting. The present study supports such a possibility. Of the amino acids whose concentration at some time falls below the fasting levels, notably alanine and glycine, but also proline, cystine, lysine, histidine and arginine, only lysine is considered indispensable for the adult human. Whether the already high nutritive value of whole egg could be increased by the addition of glycine or alanine is not known. The importance in nutrition of amino acid balance is now being recognized $(53,54)$ and the present type of study may be helpful in understanding the mechanisms involved.

The experimental data of the present work do not support the suggestion of Fisher (55) that the products of protein digestion may be absorbed as peptides rather than as free amino acids. Nonprotein combined amino acids were followed in only two subjects, but there was no evidence that they increased in concentration after the protein meal at a time when the free amino acids were rising significantly. Similar observations have been made by Christensen (2) and Dent and Schilling (6), who followed both portal and systemic venous blood, and by Stein and Moore (12).

\section{SUMMARY}

1. Free amino acids in the plasma from systemic blood have been determined by chromatography on columns of ion exchange resin in six normal subjects before, and at intervals up to eight hours after, a high-protein meal.

2. Most of the amino acids increased in concentration after the meal, but the rises did not parallel the relative amino acid composition of the food. Also, the relative distribution of the different amino acids in the plasma after the meal differed from that in the fasting state.

3. The concentrations of some of the amino acids, notably valine, leucine and isoleucine, rose markedly after the meal, and even after eight hours were higher than the fasting values.

4. Some of the amino acids, notably alanine and probably glycine, fell to levels as low as 66 per cent of the fasting values in six to eight hours. Other amino acids which decreased after six to eight hours to values significantly below fasting were arginine, cystine, histidine, lysine and proline.

5. Lysine, and to a lesser extent arginine, were characterized by a marked early rise in concentration followed by a leveling off or a decrease in the levels.

6. The amino acids which increased moderately in concentration and which did not at any time fall below the fasting levels include glutamic acid, methionine, phenylalanine, serine, threonine and tyrosine.

7. The factors which determine the effect of a protein meal on the levels of the plasma amino acids were discussed, as was also the application of the results to the study of protein nutrition.

\section{ACKNOWLEDGMENTS}

The author wishes to express her appreciation to Dr. George Bauer, Mrs. Jeanne Brown and Miss Sylvia Bunting for their valuable technical assistance, and to the laboratory staff members who served as subjects for these studies.

\section{REFERENCES}

1. Van Slyke, D. D., and Meyer, G. M. The aminoacid nitrogen of the blood. Preliminary experi- 
ments on protein assimilation. J. biol. Chem. 1912, $12,399$.

2. Christensen, H. N. Conjugated amino-acids in portal plasma of dogs after protein feeding. Biochem. J. 1949, 44, 333.

3. West, C. D., Wilson, J. L., and Eyles, R. Blood amino nitrogen levels. Changes in blood amino nitrogen levels following ingestion of proteins and of a protein hydrolysate in infants with normal and with deficient pancreatic function. Amer. J. Dis. Child. 1946, 72, 251.

4. Mellinkoff, S. M., Jenden, D. J., and Frankland, M. Postprandial serum amino acid levels in viral hepatitis. A. M. A. Arch. intern. Med. 1954, 94, 604.

5. Clemetson, C. A. B., and Churchman, J. Plasma amino-acid levels following protein ingestion by pregnant and non-pregnant subjects. J. Obstet. Gynaec. Brit. Emp. 1955, 62, 390.

6. Dent, C. E., and Schilling, J. A. Studies on the absorption of proteins: The amino-acid pattern in the portal blood. Biochem. J. 1949, 44, 318.

7. Denton, A. E., and Elvehjem, C. A. Availability of amino acids in vivo. J. biol. Chem. 1954, 206, 449.

8. Wheeler, P., and Morgan, A. F. The absorption by immature and adult rats of amino acids from raw and autoclaved fresh pork. J. Nutr. 1958, 64, 137.

9. Wynne, E. S., and Cott, C. L. Effect of food intake on amino acids in human plasma. Amer. J. clin. Nutr. 1956, 4, 275.

10. Charkey, L. W., Kano, A. K., and Hougham, D. F. Effects of fasting on blood non-protein amino acids in humans. J. Nutr. 1955, 55, 469.

11. Stein, W. H., Bearn, A. G., and Moore, S. The amino acid content of the blood and urine in Wilson's disease. J. clin. Invest. 1954, 33, 410.

12. Stein, W. H., and Moore, S. The free amino acids of human blood plasma. J. biol. Chem. 1954, 211, 915.

13. Moore, S., and Stein, W. H. Procedures for the chromatographic determination of amino acids on four per cent cross-linked sulfonated polystyrene resins. J. biol. Chem. 1954, 211, 893.

14. Moore, S., and Stein, W. H. A modified ninhydrin reagent for the photometric determination of amino acids and related compounds. J. biol. Chem. 1954, 211, 907.

15. Hirs, C. H. W., Stein, W. H., and Moore, S. The amino acid composition of ribonuclease. J. biol. Chem. 1954, 211, 941.

16. Dustin, J. P., Czajkowska, C., Moore, S., and Bigwood, E. J. A study of the chromatographic determination of amino acids in the presence of large amounts of carbohydrate. Anal. chim. Acta 1953, 9, 256.

17. Hamilton, P. B., and Van Slyke, D. D. The gasometric determination of free amino acids in blood filtrates by the ninhydrin-carbon dioxide method. J. biol. Chem. 1943, 150, 231.
18. Hiller, A., Plazin, J., and Van Slyke, D. D. A study of conditions for Kjeldahl determination of nitrogen in proteins. J. biol. Chem. 1948, 176, 1401.

19. Rees, M. W. The estimation of threonine and serine in proteins. Biochem. J. 1946, 40, 632.

20. Somogyi, M. Notes on sugar determination. J. biol. Chem. 1952, 195, 19.

21. Nelson, N. A photometric adaptation of the Somogyi method for the determination of glucose. J. biol. Chem. 1944, 153, 375.

22. Strumia, M. M., Sample, A. B., and Hart, E. D. An improved micro hematocrit method. Amer. J. clin. Path. 1954, 24, 1016.

23. Block, R. J., and Weiss, K. W. Amino Acid Handbook; Methods and Results of Protein Analysis. Springfield, Ill., Charles C Thomas, 1956.

24. McMenamy, R. H., Lund, C. C., and Oncley, J. L. Unbound amino acid concentrations in human blood plasmas. J. clin. Invest. 1957, 36, 1672.

25. Melnick, D., Oser, B. L., and Weiss, S. Rate of enzymic digestion of proteins as a factor in nutrition. Science 1946, 103, 326.

26. Denton, A. E., and Elvehjem, C. A. Enzymatic liberation of amino acids from different proteins. J. Nutr. 1953, 49, 221.

27. Sheffner, A. L., Eckfeldt, G. A., and Spector, H. The pepsin-digest-residue (PDR) amino acid index of net protein utilization. J. Nutr. 1956, 60, 105.

28. Höber, R., and Höber, J. Experiments on the absorption of organic solutes in the small intestine of rats. J. cell. comp. Physiol. 1937, 10, 401.

29. Pinsky, J., and Geiger, E. Intestinal absorption of histidine as influenced by tryptophan in the rat. Proc. Soc. exp. Biol. (N. Y.) 1952, 81, 55.

30. Wiseman, G. Absorption of amino-acids using an in vitro technique. J. Physiol. (Lond.) 1953, 120, 63.

31. Fridhandler, L., and Quastel, J. H. Absorption of amino acids from isolated surviving intestine. Arch. Biochem. 1955, 56, 424.

32. Hird, F. J. R., and Sidhu, G. S. The absorption of amino acids by twin loops of rat intestine. Biochim. biophys. Acta 1957, 25, 388.

33. Munro, H. N., and Thomson, W. S. T. Influence of glucose on amino acid metabolism. Metabolism 1953, 2, 354.

34. Steele, B. F., and Le Bovit, C. B. Leucine and histidine tolerance in the human. J. Nutr. 1951, 45, 235.

35. Gupta, J. D., Dakroury, A. M., and Harper, A. E. Observations on protein digestion in vivo. I. Rate of disappearance of ingested protein from the gastrointestinal tract. J. Nutr. 1958, 64, 447.

36. Doolan, P. D., Harper, H. A., Hutchin, M. E., and Shreeve, W. M. Renal clearance of eighteen individual amino acids in human subjects. $\mathrm{J}$. clin. Invest. $1955,34,1247$. 
37. Van Slyke, D. D., and Meyer, G. M. The fate of protein digestion products in the body. III. The absorption of amino-acids from the blood by the tissues. J. biol. Chem. 1913-14, 16, 197.

38. De Vries, A., and Alexander, B. Studies on amino acid metabolism. II. Blood glycine and total amino acids in various pathological conditions with observations on the effects of intravenously administered glycine. J. clin. Invest. 1948, 27, 655.

39. Kinsell, L. W., Harper, H. A., Barton, H. C., Hutchin, M. E., and Hess, J. R. Studies in methionine and sulfur metabolism. I. The fate of intravenously administered methionine, in normal individuals and in patients with liver damage. J. clin. Invest. 1948, 27, 677.

40. Robson, E. B., and Rose, G. A. The effect of intravenous lysine on the renal clearances of cystine, arginine and ornithine in normal subjects, in patients with cystinuria and Fanconi syndrome and in their relatives. Clin. Sci. 1957, 16, 75.

41. Onen, K. H., Wade, O. L., and Blainey, J. D. Aminoacids in hepatic venous and arterial blood investigated by paper chromatography. Lancet 1956, 271, 1075.

42. Nasset, E. S., Schwartz, P., and Weiss, H. V. The digestion of proteins in vivo. J. Nutr. 1955, 56, 83.

43. Borsook, H., Deasy, C. L., Haagen-Smit, A. J., Keighley, G., and Lowy, P. H. Metabolism of $\mathrm{C}^{14}$-labeled glycine, L-histidine, L-leucine, and L-lysine. J. biol. Chem. 1950, 187, 839.
44. Butterworth, C. E., Jr., Santini, R., Jr., and PerezSantiago, E. The absorption of glycine and its conversion to serine in patients with sprue. J. clin. Invest. 1958, 37, 20.

45. Cannon, P. R., Steffee, C. H., Frazier, L. J., Rowley, D. A., and Stepto, R. C. The influence of time of ingestion of essential amino acids upon utilization in tissue synthesis. Fed. Proc. 1947, 6, 390.

46. Geiger, E. Experiments with delayed supplementation of incomplete amino acid mixtures. J. Nutr. 1947, 34, 97.

47. Geiger, E. The role of the time factor in feeding supplementary proteins. J. Nutr. 1948, 36, 813.

48. Henderson, R., and Harris, R. S. Concurrent feeding of amino acids. Fed. Proc. 1949, 8, 385.

49. Elman, R. Time factor in retention of nitrogen after intravenous injection of a mixture of amino-acids. Proc. Soc. exp. Biol. (N. Y.) 1939, 40, 484.

50. Leverton, R. M., and Gram, M. R. Nitrogen excretion of women related to the distribution of animal protein in daily meals. J. Nutr. 1949, 39, 57.

51. Geiger, E. The role of the time factor in protein synthesis. Science 1950, 111, 594.

52. Leverton, R. M. The amino acid requirements of man in Nutrition Symposium Series, No. 8, National Vitamin Foundation, 1954, p. 55.

53. Elvehjem, C. A. Amino acid imbalance. Fed. Proc. 1956, 15, 965.

54. Flodin, N. W. Amino acid balance and efficiency of protein utilization. Metabolism 1957, 6, 350.

55. Fisher, R. B. Protein Metabolism. London, Methuen and Co., Ltd., 1954. 